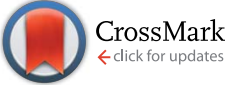

Cite this: RSC Adv., 2017, 7, 5725

Received 8th October 2016

Accepted 27th December 2016

DOI: 10.1039/c6ra24911f

www.rsc.org/advances

\section{The effects of additives on the combustion characteristics of aluminum powder in steam}

\begin{abstract}
Baozhong Zhu, Fan Li, Yunlan Sun, * Qichang Wang, Yuxin Wu and Zicheng Zhu
To develop the combustion characteristics of aluminum powder in steam, the ignition and combustion process of aluminum powder with different additives $\left(\mathrm{KBH}_{4}\right.$, ammonium perchlorate (AP) and $\left.\mathrm{NaCl}\right)$ addition at different levels were studied using a transparent pipe furnace. The temperature variation of these samples was measured using a thermocouple, and a high-speed camera was used to record combustion phenomenon. The solid combustion products of these samples with good characteristics were collected to analyze the microstructure and component. The results indicate that the ignition temperature of aluminum powder is decreased by adding these additives or increasing the content of the additive, whereas the maximum combustion temperature is different. When adding $3 \mathrm{wt} \% \mathrm{KBH}_{4}$, the maximum combustion temperature reaches up to $1404{ }^{\circ} \mathrm{C}$, which is higher than that of the original aluminum powder. However, upon addition of AP or $\mathrm{NaCl}$ the maximum combustion temperature decreases. Simultaneously, the combustion flame of aluminum powder with addition of $\mathrm{KBH}_{4}$ or AP is comparatively intense and bright, whereas the addition of $\mathrm{NaCl}$ reduces combustion intensity. The different influence mechanisms of additives on the ignition and combustion of aluminum powder are believed to be responsible for the experimental results.
\end{abstract}

\section{Introduction}

Aluminum/water propellant, which is a combination of solid energetic metal powder as fuel and water as oxidizing agent, ${ }^{1-3}$ has gained extensive attention in the field of underwater propulsion applications due to its high energy density and nontoxic combustion products. ${ }^{4,5}$ At the same time, it will be potentially applied to novel propulsion systems in the future. ${ }^{6}$ In the past, several metals had been utilized in metal/water reactions, such as beryllium, lithium, boron, magnesium and aluminum. ${ }^{7-11}$ Table 1 lists the energy density of these metal/water reactions. ${ }^{\mathbf{1 2}}$ Among these metals, beryllium, boron and lithium are found to have higher energy densities than aluminum, but these metals have several unavoidable shortcomings. Specifically, beryllium is not widely used as a result of its strong toxicity, relative scarcity, and high cost. ${ }^{13}$ Lithium is so reactive that it easily reacts with water, which leads to many problems in transportation security. ${ }^{\mathbf{1 4}}$ Ignition and combustion of boron exist many challenges due to the presence of a dense oxide $\left(\mathrm{B}_{2} \mathrm{O}_{3}\right)$ layer. ${ }^{15}$ Magnesium has a low energy density, which limits the utilization in practical applications. ${ }^{16}$ Through a comprehensive comparison of these metals, it can be concluded that aluminum has a relatively high energy density, which is recognized as one of the most suitable energy carriers. In addition, there has been

School of Energy and Environment, Anhui University of Technology, Ma'anshan, Anhui, China.E-mail: Yunlansun@163.com a strong interest in the combustion characteristics of aluminum/water system in the last four decades. ${ }^{17,18}$

However, most of studies had focused on the investigation of the reaction of aluminum and water at low temperature, ${ }^{19-21}$ and the combustion behaviors of aluminum/ice solid propellant. ${ }^{22-24}$ Only a few experimental studies were carried out on the combustion characteristics of aluminum in heated steam atmosphere..$^{25,26}$ Based on thermogravimetric analysis, Schoenitz et $a .^{27}$ found that the oxidation process of aluminum powder in steam atmosphere was similar to that in oxygen atmosphere. Shmelev et $a{ }^{28}{ }^{28}$ demonstrated experimentally the possibility of effective hydrogen generation by the reaction of molten aluminum with steam. The results showed that the maximum hydrogen yield of $40 \%$ was reached for steam flow rate not above than $0.01 \mathrm{~g} \mathrm{~s}^{-1}$. Yang et al. ${ }^{29}$ reported experimental researches on hydrogen generation by the reaction of aluminum-lithium alloy with heated steam. They found that

Table 1 Energy density of partial metal/water reactions ${ }^{12}$

\begin{tabular}{llll}
\hline Metal fuel & Oxidant & $\begin{array}{l}\text { Volumetric energy } \\
\left.\text { density/( } \mathrm{J} \mathrm{m}^{-3}\right)\end{array}$ & $\begin{array}{l}\text { Mass energy } \\
\text { density } /\left(\mathrm{kJ} \mathrm{g}^{-1}\right)\end{array}$ \\
\hline $\mathrm{Be}$ & $\mathrm{H}_{2} \mathrm{O}$ & 67.200 & 36.204 \\
$\mathrm{~B}$ & $\mathrm{H}_{2} \mathrm{O}$ & 44.100 & 18.900 \\
$\mathrm{Al}$ & $\mathrm{H}_{2} \mathrm{O}$ & 40.950 & 15.485 \\
$\mathrm{Mg}$ & $\mathrm{H}_{2} \mathrm{O}$ & 22.764 & 13.104 \\
$\mathrm{Li}$ & $\mathrm{H}_{2} \mathrm{O}$ & 16.926 & 31.878
\end{tabular}


the pores in the $\mathrm{LiAlO}_{2}$ products took an important role in improving the reactivity of aluminum and steam. On the other hand, additives are recognized as one of the factors to influence on the combustion process of aluminum and water. Vasilev et $a l .{ }^{30}$ studied the effects of fluorides such as KF, NaF, LiF and $\mathrm{AlF}_{3}$ on the ignition and combustion of aluminum and water. The results showed that $\mathrm{NaF}$ and KF had greater effects on the burning rate than the other additives. Sundaram et al. ${ }^{31}$ reported that the combustion flame temperature and linear burning rate of aluminum/water mixtures with addition of alane $\left(\mathrm{AlH}_{3}\right)$ were lower than those of aluminum/water mixtures without addition of $\mathrm{AlH}_{3}$. Sun et al. ${ }^{32}$ reported that $\mathrm{PEO}$ addition improved the ignition and combustion characteristics of aluminum/water mixtures. They found that the mixtures of aluminum and water could hardly be ignited in argon atmosphere, whereas the mixture with addition of $1 \mathrm{wt} \%$ or $3 \mathrm{wt} \%$ PEO could be ignited. All above mentioned studies indicated that the addition of additives could be one effective method to improve the combustion characteristics of aluminum powder in steam.

Borohydrides of light metals are known to be excellent sources of hydrogen, such as sodium borohydride $\left(\mathrm{NaBH}_{4}\right)$ and potassium borohydride $\left(\mathrm{KBH}_{4}\right)$, which can be generated by the reactions of these compounds with water or oxidizing agents. $\mathrm{KBH}_{4}$ is a white loose powder with a melting point of $500{ }^{\circ} \mathrm{C}$. Especially, it belongs to a kind of materials with the high gravimetric hydrogen density and good hydrolytic characteristic. Recently, Shafirovich et al. ${ }^{33,34}$ first reported their experimental studies on the combustion of metal borohydride/aluminum/water mixtures. Sodium chloride $(\mathrm{NaCl})$ is a white crystalline compound with a melting point of $801{ }^{\circ} \mathrm{C}$ and a boiling point of $1465{ }^{\circ} \mathrm{C}$. Some studies reported that adding $\mathrm{NaCl}$ was conducive to the penetration of water through alumina layer and accelerated hydrogen production at relatively low reaction temperature. ${ }^{35,36}$ On the other hand, aluminum/ water propellant is normally used in underwater propulsion system and the available oxidizing agent is sea water, which is rich in NaCl. Ammonium perchlorate (AP) with a decomposition temperature of $300{ }^{\circ} \mathrm{C}$ is a white spherical crystal. It is easily deliquesces and has a strong oxidized characteristic. AP has been constantly used as the most common oxidizer for composite solid propellants (CSPs), ${ }^{37}$ which can use to improve the combustion behaviors of CSPs. However, there are few experimental studies on the combustion process of aluminum powder with addition of above mentioned three additives in heated steam. Therefore, this study was undertaken to investigate the effects of $\mathrm{KBH}_{4}, \mathrm{AP}$ and $\mathrm{NaCl}$ on the reactions of aluminum powder with heated steam at high temperatures by a transparent pipe furnace. The objective of the study is to understand how to vary the ignition and combustion characteristics of aluminum powder in steam with addition of these additives at different levels.

\section{Experimental section}

\section{Sample preparation}

All the reactants required in the study were listed in Table 2, including particle size, chemical purity, grade, and the supplier. The scanning electron microscopy (SEM) image of Al powder with
Table 2 Reactants used in the study

\begin{tabular}{|c|c|c|c|c|}
\hline Reagent & $\begin{array}{l}\text { Particle } \\
\text { size }\end{array}$ & $\begin{array}{l}\text { Purity } \\
(\%)\end{array}$ & Grade & Supplier \\
\hline $\mathrm{Al}$ & $50 \mathrm{~nm}$ & 80.8 & Common & $\begin{array}{l}\text { Jiaozuo Nano } \\
\text { Material Company }\end{array}$ \\
\hline $\mathrm{KBH}_{4}$ & - & 99.9 & Analytical & Aladdin \\
\hline $\mathrm{AP}$ & $10 \mu \mathrm{m}$ & 99.0 & Technical & $\begin{array}{l}\text { Xi'an Modern Chemistry } \\
\text { Research Institute }\end{array}$ \\
\hline $\mathrm{NaCl}$ & - & 99.5 & Analytical & Aladdin \\
\hline
\end{tabular}

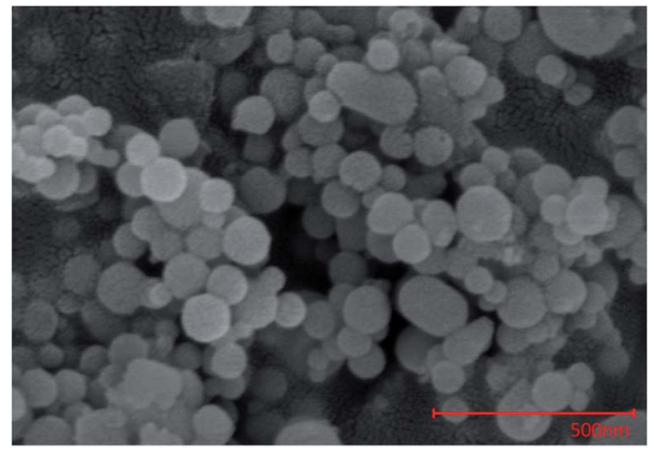

Fig. 1 SEM image of $50 \mathrm{~nm}$ Al powder.

the average diameter of $50 \mathrm{~nm}$ was shown in Fig. 1 . The active aluminum content was approximately $80.8 \%$, which was measured by the principle of permanganatometric method..$^{38}$ The remaining $19.2 \%$ substance was $\mathrm{Al}_{2} \mathrm{O}_{3}$ covered on the $\mathrm{nAl}$ powder surface.

Additionally, deionized water was used to produce steam. Nano-sized aluminum ( $\mathrm{nAl}$ ) powder was adequately mixed with different additives $\left(\mathrm{KBH}_{4}, \mathrm{AP}\right.$ and $\left.\mathrm{NaCl}\right)$ in mass ratio of $1 \mathrm{wt} \%$, $3 \mathrm{wt} \%$ and $5 \mathrm{wt} \%$ (additive-to-nAl - mass ratios), respectively.

\section{Apparatus and measurement methods}

The experiments were performed in a transparent pipe furnace with an inner diameter of $70 \mathrm{~mm}$ and a length of $520 \mathrm{~mm}$, shown in Fig. 2. The heating power of the transparent pipe furnace was controlled by a thermoregulator. To make nAl powder react as completely as possible, the temperature inside the pipe furnace was first heated to $700{ }^{\circ} \mathrm{C}$, and then the steam was flowed into the pipe furnace to expel air. The steam flow rate was controlled through the steam generator. The alumina crucible with a sample $(\sim 300 \mathrm{mg})$ was put into the pipe furnace. An S-type thermocouple was inserted in the middle of sample to monitor the temperature variation. The temperature data were recorded by an Agilent (34972A, USA). Combustion processes of the samples were recorded using a high-speed camera (Phantom V311, VRI, USA). The experiments were carried out at the atmospheric pressure (0.1 $\mathrm{MPa})$.

The solid combustion products were collected and characterized by scanning electron microscopy combined with energy dispersive X-ray (SEM-EDS, SU-70, Japan) and X-ray diffraction (XRD, D8 Advance, Bruker) using non-monochromated $\mathrm{Cu}-\mathrm{K} \alpha$ $\mathrm{X}$-radiation. 


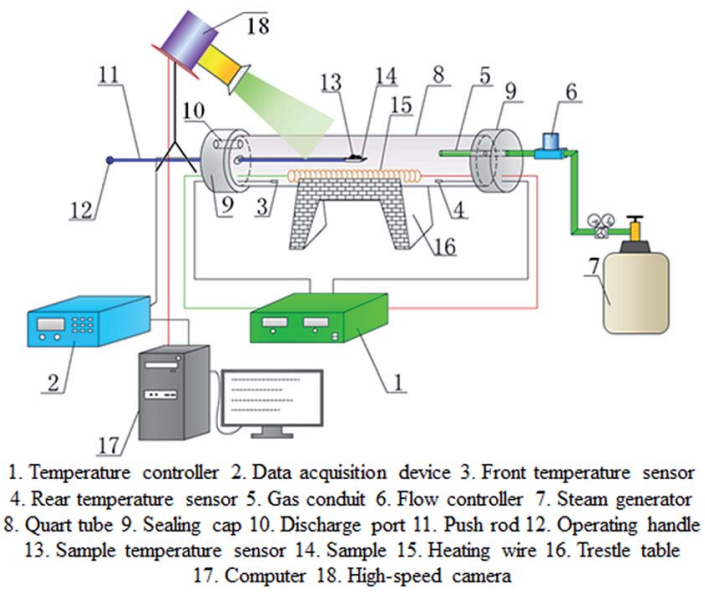

Fig. 2 Schematic diagram of the experimental apparatus.

\section{Results and discussion}

\section{Effects of additives on combustion characteristics}

Combustion characteristics of a sample examined in this study include its ignition temperature and maximum combustion temperature during combustion. The combustion characteristics are related to the combustion conditions and compositions of samples. One set of the results of the combustion temperature evolution curve of nAl sample in steam is presented in Fig. 3. Obviously, according to the three temperatures at the three marked points on the curve, i.e., a low temperature $\left(T_{\mathrm{o}}\right)$ of $100{ }^{\circ} \mathrm{C}$ at $t=0 \mathrm{~s}$ (the moment at $100{ }^{\circ} \mathrm{C}$ is recorded as $t=0 \mathrm{~s}$ ), the ignition temperature $\left(T_{\mathrm{i}}\right)$, and the maximum combustion temperature $\left(T_{\mathrm{m}}\right)$, the combustion process can be divided into three stages: a slowly heating zone (Stage I), a rapidly reaction zone (Stage II), and a cooling zone (Stage III). In Stage I, the oxidation reaction of $\mathrm{nAl}$ in steam is essentially absent at the beginning due to the low temperature. As the sample is heated, the temperature of $\mathrm{nAl}$ continues to increase. Thus, the reactions of $\mathrm{nAl}$ in steam are gradually accelerated, and the sample is ignited at $473{ }^{\circ} \mathrm{C}$. In Stage I, the rising process of temperature lasts about 35 s. In Stage II, the temperature of the mixture

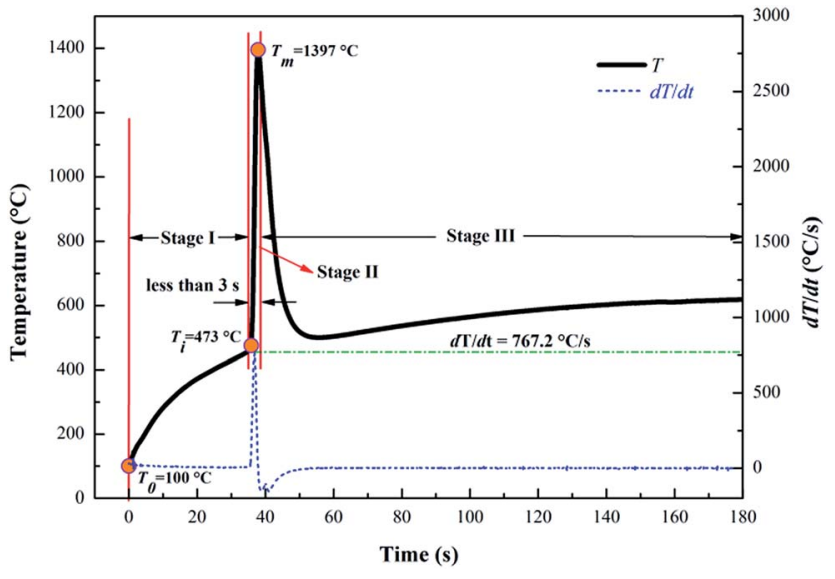

Fig. 3 The temperature evolution of nAl sample in steam. rapidly increases at about $38 \mathrm{~s}$ with a maximum temperature change rate of $767.2{ }^{\circ} \mathrm{C} \mathrm{s}^{-1}$. The similar rapid temperature change was also reported by the previous work. ${ }^{39}$ The point of the maximum temperature change rate on the curve is regarded as the ignition temperature $\left(T_{\mathrm{i}}\right)$ which is $473{ }^{\circ} \mathrm{C}$ for nAl. In addition, the time span from $473{ }^{\circ} \mathrm{C}$ to the peak temperature of $1397{ }^{\circ} \mathrm{C}$ is less than $3 \mathrm{~s}$. The obtained high heating rate indicates that the reaction of $\mathrm{nAl}$ in steam is violent with a large amount of heat released. In Stage III, the remaining active aluminum powder is continuously consumed and the temperature decreases rapidly until the reactive aluminum powder is consumed.

The combustion process of $\mathrm{nAl}$ particle in steam is schematically illustrated in Fig. 4, which includes a series of physical and chemical behaviours. In Stage I, the nAl core is coated by a thin amorphous layer of $\mathrm{Al}_{2} \mathrm{O}_{3}$, which prevents $\mathrm{H}_{2} \mathrm{O}$ molecules from contacting the fresh $\mathrm{nAl}$ core. Meanwhile, a phase transformation of $\mathrm{Al}_{2} \mathrm{O}_{3}$ shell occurs, which transforms amorphous $\mathrm{Al}_{2} \mathrm{O}_{3}$ to $\gamma-\mathrm{Al}_{2} \mathrm{O}_{3}{ }^{40}$ Because the density of $\gamma-\mathrm{Al}_{2} \mathrm{O}_{3}$ (3.65-3.67 $\mathrm{g}$ $\left.\mathrm{cm}^{-3}\right)$ is higher than that of amorphous $\mathrm{Al}_{2} \mathrm{O}_{3}(2.45-3.38 \mathrm{~g}$ $\left.\mathrm{cm}^{-3}\right),{ }^{41}$ the newly formed $\gamma-\mathrm{Al}_{2} \mathrm{O}_{3}$ will be under greater compression at the metal-oxide interface. The tensile stress of $\mathrm{Al}_{2} \mathrm{O}_{3}$ shell will be developed due to their enforced expansion, which produces tensile cracking at the end of Stage I. ${ }^{42}$ In Stage II, the continued $\mathrm{H}_{2} \mathrm{O}$ molecules would present on the fresh nAl core surface as a result of diffusion of $\mathrm{H}_{2} \mathrm{O}$ molecules through the cracks of oxide shell, which induces the fresh nAl powder to ignite. The reaction of $\mathrm{nAl}$ powder with steam releases a large amount of heat, resulting in increasing the temperature of $\mathrm{nAl}$ core and accelerating its melting. At the same time, the phase transformation happens continuously. During the melting of the nAl core, the shell rupture occurs due to the differential pressure inside the shell and the phase transformation at the

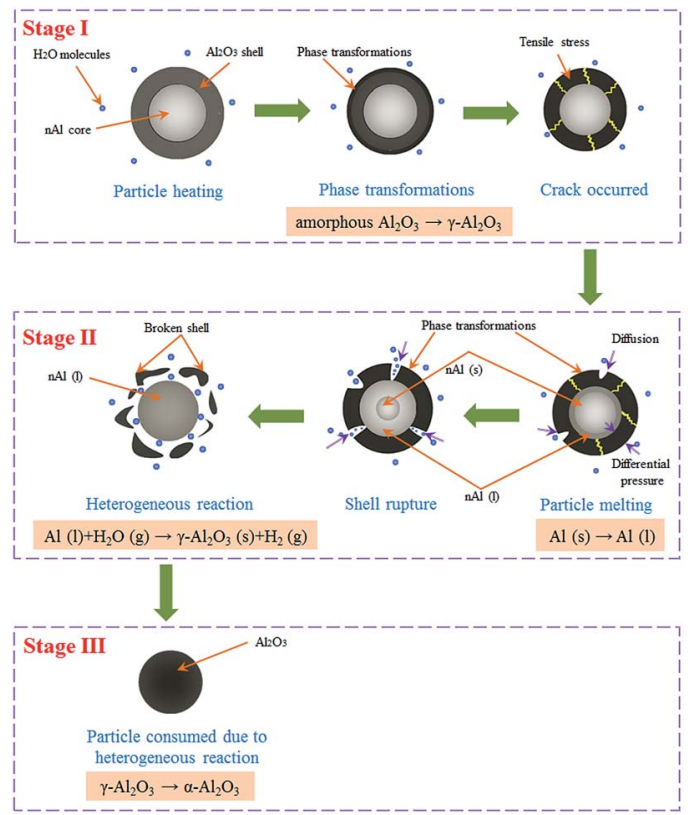

Fig. 4 A schematic depiction of the combustion process of $\mathrm{nAl}$ particle in steam. 
shell surface. As a result, the shell breaks into many small pieces and detaches from the nAl core, and the nAl core is completely exposed to steam. At this point, the heterogeneous reactions between the exposed $\mathrm{nAl}$ and the $\mathrm{H}_{2} \mathrm{O}$ molecules proceed rapidly and the temperature increases from $473{ }^{\circ} \mathrm{C}$ to $1397{ }^{\circ} \mathrm{C}$ in less than $3 \mathrm{~s}$. In Stage III, the remaining $\mathrm{nAl}$ is consumed gradually and generates a new layer of $\mathrm{Al}_{2} \mathrm{O}_{3}$. The product on the surface of $\mathrm{nAl}$ core is mainly composed of denser $\alpha-\mathrm{Al}_{2} \mathrm{O}_{3}$, which results in a more difficult diffusion of oxidant.

To verify the correctness and reasonable of the combustion behaviors of nAl particle in steam, a standard theory of equilibrium thermodynamics is used to obtain the melting temperature of solid particle. In this theory, solid particle is considered as the structure of spherical shell. The melting temperature is the equilibrium temperature between a solid sphere and concentric liquid shell. Based on this approach, Wronski et al. ${ }^{43}$ developed the following relationship for the particle dependent melting temperature $\left(T_{\mathrm{m}}\right)$ as a function of particle diameter $(d)$,

$$
T_{\infty}-T_{\mathrm{m}}=\frac{2 T_{\infty}}{\Delta H_{\text {fus }}}\left\{\frac{\sigma_{\mathrm{sl}}}{\rho_{\mathrm{s}}\left(\frac{d}{2}-\tau\right)}+\frac{\sigma_{\mathrm{lv}}}{r}\left(\frac{1}{\rho_{\mathrm{s}}}-\frac{1}{\rho_{\mathrm{l}}}\right)\right\}
$$

In this equation, $T_{\infty}$ is the bulk melting temperature of $\mathrm{Al}, \tau$ is the thickness of liquid layer, $\sigma_{\mathrm{sl}}$ and $\sigma_{\mathrm{lv}}$ are the surface tensions of solid-liquid and liquid-vapor, $\rho_{\mathrm{s}}$ and $\rho_{\mathrm{l}}$ are the density of solid and liquid, and $\Delta H_{\text {fus }}$ is the latent heat of fusion. It is noted that the molten $\mathrm{Al}$ core expands and induces cracks on the surface of the particle where the liquid $\mathrm{Al}$ can react with steam, so we assume that no $\mathrm{Al}$ vapor generates and the surface tension of liquid-vapor is neglected, which is similar to the analysis of Granier et al. ${ }^{44}$ Eqn (1) is rewritten as the following eqn (2):

$$
T_{\mathrm{m}}=T_{\infty}-\frac{2 T_{\infty}}{\Delta H_{\text {fus }}}\left\{\frac{\sigma_{\mathrm{sl}}}{\rho_{\mathrm{s}}\left(\frac{d}{2}-\tau\right)}\right\}
$$

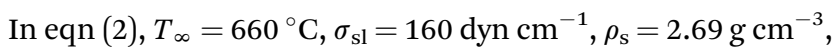
and $\Delta H_{\text {fus }}=400 \mathrm{~J} \mathrm{~g}^{-1} \cdot{ }^{44,45} \mathrm{In}$ addition, $\tau$ is assumed to be on the order of $30 \AA$ ( $1 \AA=0.1 \mathrm{~nm}), d=50 \mathrm{~nm}$. The calculated $T_{\mathrm{m}}=$ $625{ }^{\circ} \mathrm{C}$. It can be seen from Fig. 3 that the ignition temperature of $\mathrm{nAl}$ is $473^{\circ} \mathrm{C}$, which reduces by a factor of $\sim 1.3$ as compared to its melting temperature. This result indicates that the ignition occurs before nAl particles are completely melted into liquid phase and further demonstrates that the depiction of the combustion behaviors of $\mathrm{nAl}$ particle in steam is reasonable.

One set of results of the combustion temperature curves of $\mathrm{nAl}$ with addition of the three additives are investigated here, namely $\mathrm{KBH}_{4}$, AP and $\mathrm{NaCl}$ at different levels as shown in Fig. 5 . It is evident that these additives or the same additive at different levels have strong influences on the ignition and combustion temperatures of $\mathrm{nAl}$ in steam. The ignition temperature and the maximum combustion temperature curves of these samples are presented in Fig. 6. The error bars represent the standard deviation of the experimental data.

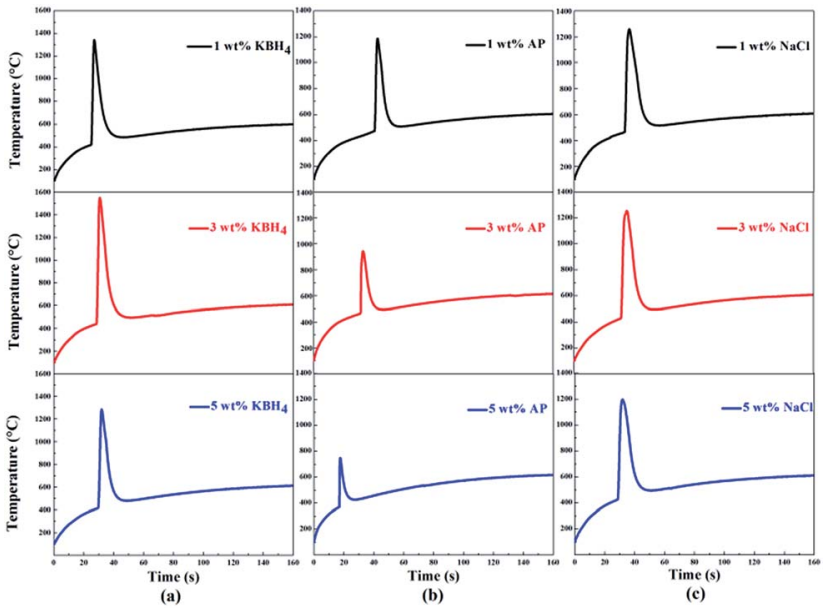

Fig. 5 Ignition and combustion temperature curves of nAl powder with the addition of three additives at different levels in steam (a) $\mathrm{KBH}_{4}$, (b) AP, and (c) $\mathrm{NaCl}$.

As shown in Fig. 6(a), the ignition temperature of nAl powder first decreases and then increases with the increase of $\mathrm{KBH}_{4}$ addition. The nAl with $3 \mathrm{wt} \% \mathrm{KBH}_{4}$ addition shows a minimum ignition temperature of $429{ }^{\circ} \mathrm{C}$ and the decreasing range is $\sim 8.54 \%$. As the content of $\mathrm{KBH}_{4}$ increases further to $5 \mathrm{wt} \%$, the ignition temperature increases to $452{ }^{\circ} \mathrm{C}$, which is only $16{ }^{\circ} \mathrm{C}$ lower than that of the original nAl powder. At the same time, it can be seen from Fig. 6(a) that the maximum combustion temperature of $\mathrm{nAl}$ powder first increases and then decreases as the content of $\mathrm{KBH}_{4}$ increases from $1 \mathrm{wt} \%$ to $5 \mathrm{wt} \%$. When adding $3 \mathrm{wt} \% \mathrm{KBH}_{4}$, the maximum combustion temperature of $\mathrm{nAl}$ powder significantly increases to $1404^{\circ} \mathrm{C}$ and the increasing range is $\sim 1.59 \%$ compared with the original $\mathrm{nAl}$ powder. These results indicate that the ignition and combustion performances of $\mathrm{nAl}$ powder with $3 \mathrm{wt} \% \mathrm{KBH}_{4}$ addition are optimal. It is analyzed that the ignition and combustion temperature is mainly affected by hydrolysis characteristics of $\mathrm{KBH}_{4}$ in steam and the hydrolysis reaction is as follows:

$$
\mathrm{KBH}_{4}+2 \mathrm{H}_{2} \mathrm{O} \rightarrow \mathrm{KBO}_{2}+4 \mathrm{H}_{2}
$$

In this reaction, the heat generated through hydrolysis reaction promotes the ignition of $\mathrm{nAl}$ powder in steam. On the other hand, the hydrolysis products $\left(\mathrm{KBO}_{2}\right)$ are generated and cover on the surface of nAl powder, which hinder the nAl-steam reaction and correspondingly decrease the maximum combustion temperature of $\mathrm{nAl}$ powder. Therefore, different contents of $\mathrm{KBH}_{4}$ addition have different effects on the ignition temperature and the maximum combustion temperature.

Fig. 6(b) shows the ignition temperature and the maximum combustion temperature curves of $\mathrm{nAl}$ with the addition of different contents of AP in steam. Noted worthily, as the AP content is increased from $0 \mathrm{wt} \%$ to $5 \mathrm{wt} \%$, the ignition temperature and the maximum combustion temperature of $\mathrm{nAl}$ both dramatically decrease. To be specific, the descending value of the ignition temperature range is from 468 to $412{ }^{\circ} \mathrm{C}$, and the decreasing value range of the maximum combustion temperature 

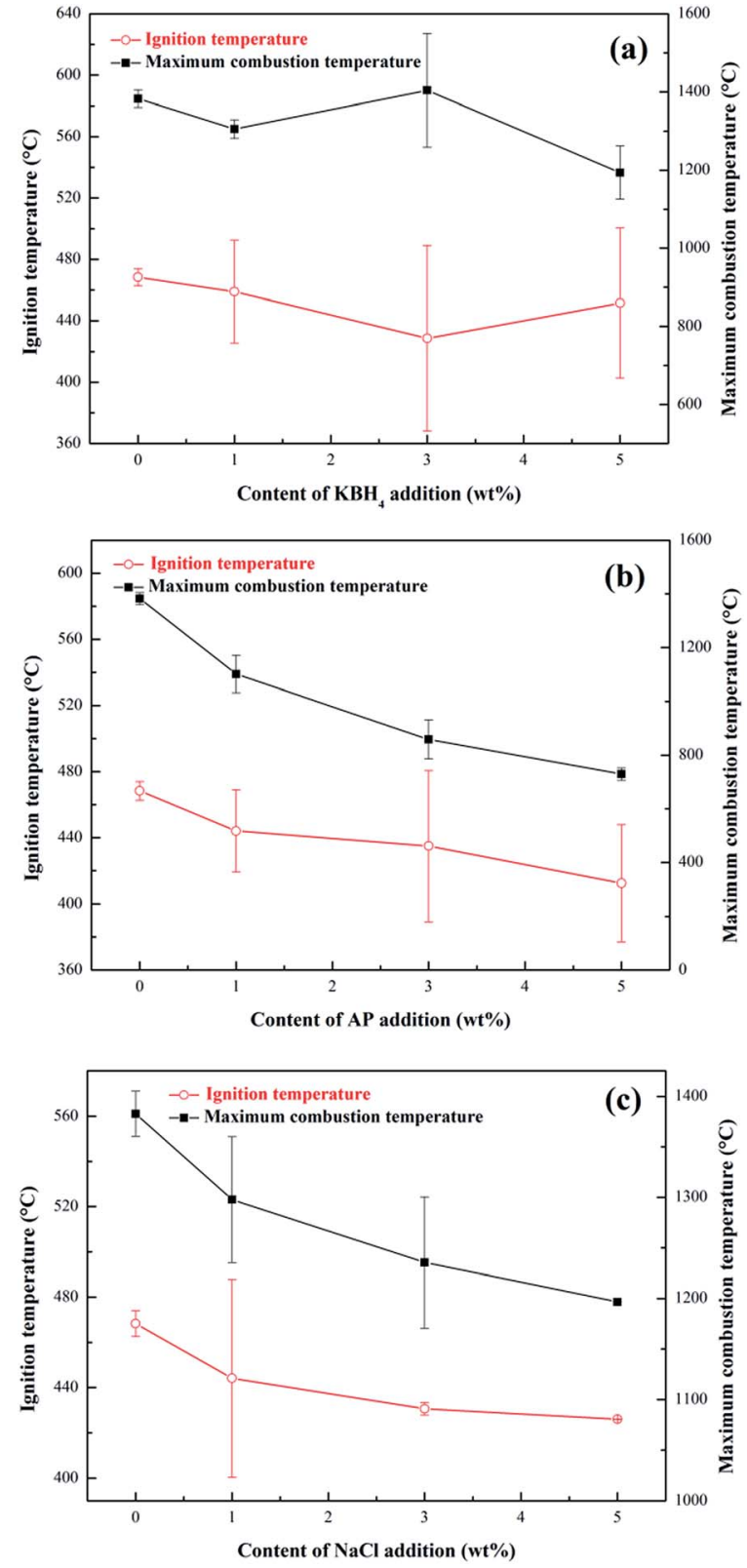

Fig. 6 Ignition and the maximum combustion temperature curves of nAl powder with the addition of three additives in steam (a) $\mathrm{KBH}_{4}$, (b) $\mathrm{AP}$, and (c) $\mathrm{NaCl}$.

is from 1383 to $729{ }^{\circ} \mathrm{C}$, comparing to that of $\mathrm{nAl}$ without the addition of AP. These results indicate that AP addition is significantly beneficial in improving the ignition performance of $\mathrm{nAl}$ in steam. It is known that abundant gaseous products, such as nitrogen oxide (NO), chlorine $\left(\mathrm{Cl}_{2}\right)$, water $\left(\mathrm{H}_{2} \mathrm{O}\right)$ and oxygen $\left(\mathrm{O}_{2}\right)$, are produced during the decomposition of AP. ${ }^{46}$ The decomposition reaction of AP is as follows:

$$
2 \mathrm{NH}_{4} \mathrm{ClO}_{4} \rightarrow 2 \mathrm{NO}+\mathrm{O}_{2}+\mathrm{Cl}_{2}+4 \mathrm{H}_{2} \mathrm{O}
$$

To our knowledge, combustion is a typical thermodynamic proces, ${ }^{47}$ and the maximum combustion temperature of the sample is influenced by the competition between the heat production of exothermic reaction of oxidizing species (such as $\mathrm{nAl}-\mathrm{H}_{2} \mathrm{O}$ reactions and $\mathrm{nAl}-\mathrm{O}_{2}$ reactions) and the heat absorption of AP decomposition. The released $\mathrm{O}_{2}$ reacts more easily with nAl than $\mathrm{H}_{2} \mathrm{O}$ when $\mathrm{AP}$ is added into nAl powder, thus promoting the ignition of $\mathrm{nAl}$ powder. Therefore, the ignition temperature significantly decreases with the increase of AP addition. However, during the decomposition of AP, the amount of heat absorption is much larger than the amount of heat production. In addition, a large amount of products including $\mathrm{NO}, \mathrm{Cl}_{2}$, and small solids are extrusive, which lead to the increase of the two-phase flow losses, so AP addition noticeably decreases the maximum combustion temperature.

The ignition temperature and the maximum combustion temperature curves of the $\mathrm{nAl}$ with the addition of $\mathrm{NaCl}$ are shown in Fig. 6(c). The test results are similar to the results of nAl with AP addition. Namely, the ignition temperature and the maximum combustion decrease with increasing $\mathrm{NaCl}$ addition. Among these samples, the nAl with $5 \mathrm{wt} \% \mathrm{NaCl}$ addition has a minimum ignition temperature of $426{ }^{\circ} \mathrm{C}$ and the decreasing range is $\sim 8.89 \%$ compared with original nAl powder, whereas it has a minimum combustion temperature of $1196{ }^{\circ} \mathrm{C}$. The minimum combustion temperature is $187^{\circ} \mathrm{C}$ lower than that of original nAl powder. This can be attributed to the dissolution of $\mathrm{NaCl}$ in steam to form $\mathrm{Cl}^{-}$, which can penetrate the oxide films on the nAl surface to make it loose and cracked. ${ }^{48}$ Clearly, the nAl powder with damaged oxide film is known to burn easily when it is exposed to steam. Thus, $\mathrm{NaCl}$ which is added into $\mathrm{nAl}$ accelerates the exposure of the fresh surface of nAl particle to steam, leading to a lower ignition temperature. However, after the oxide film is destroyed, $\mathrm{NaCl}$ may deposit on the fresh surface of nAl to act as an inert material that inhibits the oxidation process of $\mathrm{nAl},{ }^{49}$ so the maximum combustion temperature decreases with increasing the content of $\mathrm{NaCl}$ addition.

Based on the discussed above, these additives have significant effects on the ignition and combustion performances of $\mathrm{nAl}$ in steam. To reveal these additives how to affect the combustion characteristics of $\mathrm{nAl}$ powder and what mechanisms are responsible for these effects, the combustion phenomena and combustion products of nAl with $5 \mathrm{wt} \% \mathrm{KBH}_{4}$, $\mathrm{AP}$, and $\mathrm{NaCl}$ addition in steam are further investigated.

\section{Effects of additives on combustion phenomena}

The combustion processes of nAl without and with 5 wt\% addition of the three additives in steam are recorded by a highspeed camera, as shown in Fig. 7. The onset time of ignition is taken as $t=0 \mathrm{~s}$. After the onset of ignition, it can be found from Fig. 7(a) that the sample surface begins to appear as small bright spot at $0.35 \mathrm{~s}$ because the $\mathrm{nAl}$ powder is locally ignited first and then the burning region gradually expands. The whole flame spread process lasts for at least $4.57 \mathrm{~s}$. Nevertheless, the diffusion combustion of $\mathrm{nAl}$ produces a layer of alumina that slows down or even inhibits the access of $\mathrm{H}_{2} \mathrm{O}$ molecules to the remaining $\mathrm{nAl}$ surface. Thus, the available combustion area slowly shrinks until the flame extinguishes.

The three typical additives investigated in this study affect not only the maximum combustion temperature and the 

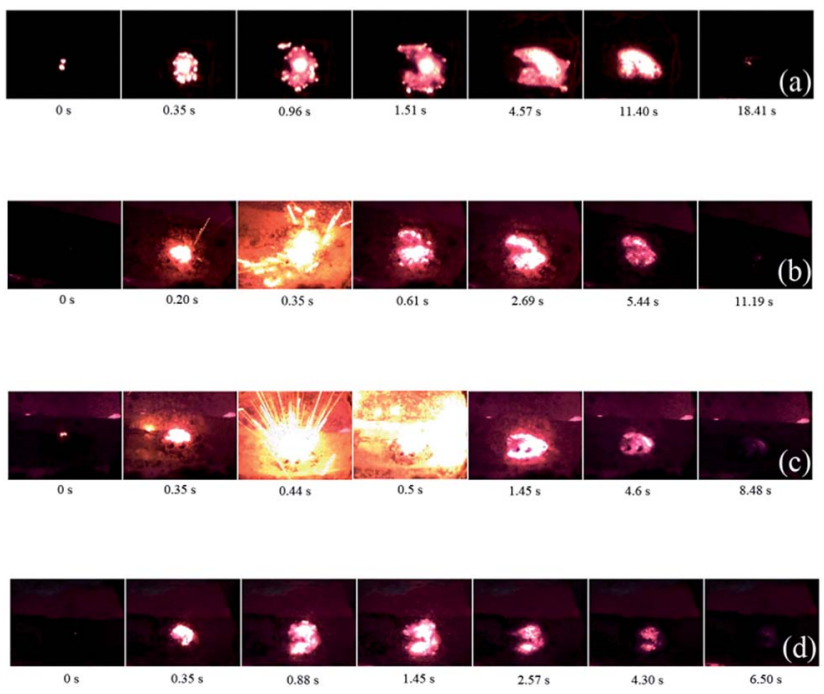

Fig. 7 Evolution of the combustion process without and with $5 \mathrm{wt} \%$ addition of three additives (a) original $\mathrm{nAl}$, (b) $\mathrm{nAl}$ with $5 \mathrm{wt} \% \mathrm{KBH}_{4}$ addition, (c) nAl with 5 wt\% AP addition and (d) nAl with 5 wt $\% \mathrm{NaCl}$ addition.

ignition temperature but also the combustion process. As can be observed in Fig. 7(b) and (c), the combustion processes of nAl with $5 \mathrm{wt} \% \mathrm{KBH}_{4}$ and $5 \mathrm{wt} \%$ AP addition share some similarities and can be divided into three stages. Firstly, at the early stage of ignition, the burning is intense and the flame is bright. Secondly, the burning region expands rapidly to the surrounding with intense flame radiation and some explosionlike pattern of burning aluminum particles. As shown in Fig. 7(c), it can be seen that the combustion of nAl with $5 \mathrm{wt} \%$ $\mathrm{AP}$ addition is more intense than that of nAl with $5 \mathrm{wt} \% \mathrm{KBH}_{4}$ addition at $0.44 \mathrm{~s}$. Lastly, the combustion after the violent explosion-like burning gets into a slowly varying stage. In this stage, the remaining unburnt nAl continues to be oxidized until depletion. As shown in Fig. 7(d), compared with the case of nAl without additives (shown in Fig. 7(a)), it is noted that the combustion process of $\mathrm{nAl}$ with $5 \mathrm{wt} \% \mathrm{NaCl}$ addition is overall similar but slightly different. The bright zone is obviously smaller and the burning is somewhat less intense, as manifested by the lower flame intensities.

\section{Analysis of combustion products}

Effects of the three additives on the particle shape and morphology of the combustion products of $\mathrm{nAl}$ in steam were also investigated. As shown in Fig. 8, SEM micrographs of the combustion products clearly display some differences in the surface morphologies due to the addition of three different additives.

Fig. 8(a) shows a typical SEM image of the combustion products of the original nAl powder. The combustion products of $\mathrm{nAl}$ powder consist of some irregular blocks. The sizes of the blocks are mainly ranging in several microns, which are much larger than the initial aluminum particle size $(50 \mathrm{~nm})$. In addition, the surfaces of coarse blocks are covered by a layer of floccules. In our previous study, ${ }^{50}$ we have demonstrated that
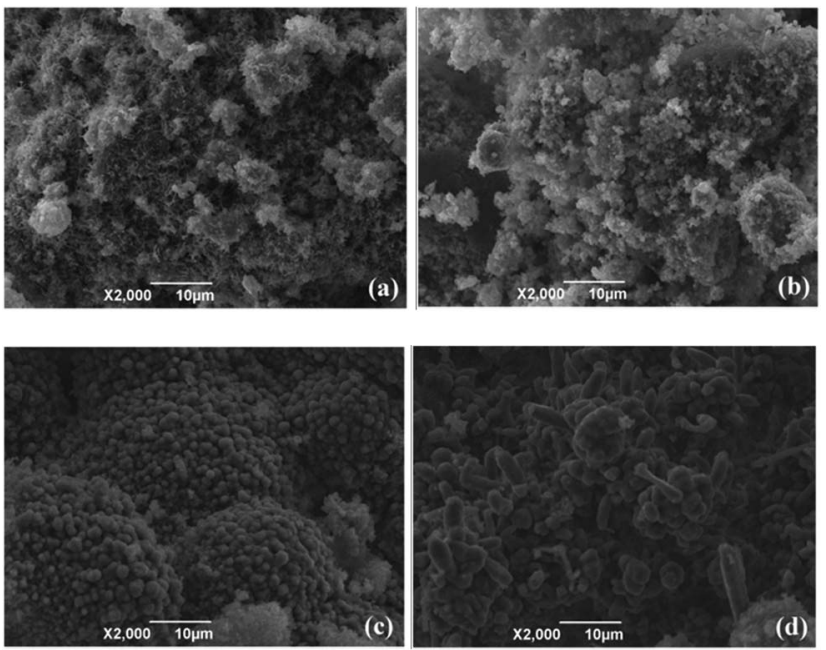

Fig. 8 SEM micrographs of the combustion products of nAl in steam (a) original $\mathrm{nAl}$, (b) nAl with $5 \mathrm{wt} \% \mathrm{KBH}_{4}$ addition, (c) nAl with 5 wt\% $\mathrm{AP}$ addition and (d) nAl with $5 \mathrm{wt} \% \mathrm{NaCl}$ addition.

the floccules are composed of $\mathrm{Al}$ and $\mathrm{Al}_{2} \mathrm{O}_{3}$. As shown in Fig. 8(b), adding $5 \mathrm{wt} \% \mathrm{KBH}_{4}$ into nAl results in a special morphology that contains a number of fluffy particles and the average diameters of these particles are about $1.0 \mu \mathrm{m}$. This phenomenon may be caused by the hydrolysis of $\mathrm{KBH}_{4}$, which produces hydrogen to release. The release process of hydrogen leads to the formation of fluffy particles. The typical surface morphology of the combustion products of nAl with $5 \mathrm{wt} \%$ AP addition in steam is displayed in Fig. 8(c). It can be observed that the combustion products consist of a lot of smooth spherical particles on the surface of some much larger structures. The average diameter of these spherical particles is approximately $2.0 \mu \mathrm{m}$. These spherical particles may be composed of $\mathrm{Al}_{2} \mathrm{O}_{3}$ as the main products based on our recently research. ${ }^{50}$ This can be explained by the fact that nAl with $5 \mathrm{wt} \%$ AP addition burns more completely than the original nAl powder due to the high oxidizing ability of the decomposition products of AP. In addition, nAl with $5 \mathrm{wt} \%$ AP addition burns much violently as evidenced by the explosion-like intense burning shown in Fig. 7(c). It can be seen from Fig. 8(d) that the morphology of the combustion products of nAl with $5 \mathrm{wt} \% \mathrm{NaCl}$ addition is noticeably different from that of the other samples. The macroscopical morphologies of combustion products mainly include rod-shaped and irregular particles. The surfaces of these particles are non-uniformly, but entirely. The lengths of these rod-shaped particles vary from 2.8 to $12.4 \mu \mathrm{m}$ and the diameters are about $5.3 \mu \mathrm{m}$. Based on the SEM images shown in Fig. 8, it can be concluded that addition of the three additives have marked influences on the surface morphologies and sizes of combustion products of $\mathrm{nAl}$ powder in steam.

To further understand the effects of $\mathrm{KBH}_{4}, \mathrm{AP}$, and $\mathrm{NaCl}$ addition on these combustion products in steam, the phase structures of the combustion products collected after experiments are analyzed by XRD. Fig. 9 shows the XRD patterns for the combustion products of four different samples. The Al peaks, 


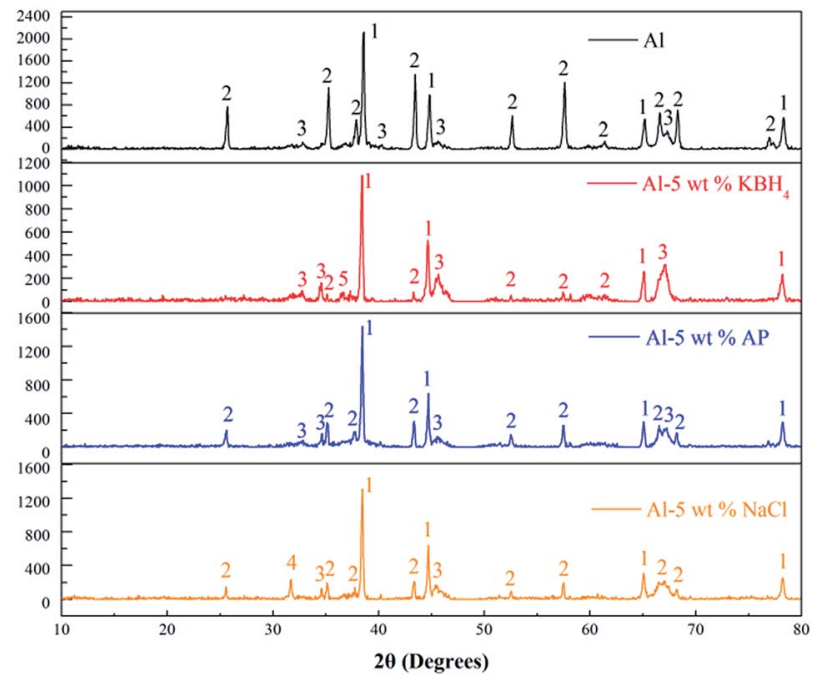

Fig. 9 XRD patterns of the combustion products of $\mathrm{nAl}$ in steam without and with 5 wt\% addition of the three additives (1: $\mathrm{Al}, 2: \alpha-\mathrm{Al}_{2} \mathrm{O}_{3}$, 3: $\gamma-\mathrm{Al}_{2} \mathrm{O}_{3}, 4: \mathrm{NaCl}, 5: \mathrm{KBO}_{2}$ ).

which are marked as (1), are clearly present in the spectrum for all of the samples. This is a clear indication that the reaction of $\mathrm{nAl}$ with steam is incomplete. The peaks of $\mathrm{Al}, \alpha-\mathrm{Al}_{2} \mathrm{O}_{3}$, and $\gamma-\mathrm{Al}_{2} \mathrm{O}_{3}$ (marked as 1, 2, and 3, respectively) are detected in all the combustion products of $\mathrm{nAl}$ without and with addition of the three additives.

For $\mathrm{nAl}$ with $5 \mathrm{wt} \% \mathrm{KBH}_{4}$ addition (the second panel), there is a $\mathrm{KBO}_{2}$ peak (marked as 5) in addition to $\mathrm{Al}, \alpha-\mathrm{Al}_{2} \mathrm{O}_{3}$ and $\gamma$ $\mathrm{Al}_{2} \mathrm{O}_{3}$ peaks. The presence of $\mathrm{KBO}_{2}$ in the combustion products further indicates that the hydrolysis processes of $\mathrm{KBH}_{4}$ actually take place during combustion. Nevertheless, only the peaks of $\mathrm{Al}, \alpha-\mathrm{Al}_{2} \mathrm{O}_{3}$, and $\gamma-\mathrm{Al}_{2} \mathrm{O}_{3}$ are observed in the sample of nAl with 5 wt $\%$ AP addition (the third panel). This result demonstrates that AP is decomposed completely in the reaction of $\mathrm{nAl}$ and steam. For $\mathrm{nAl}$ with $5 \mathrm{wt} \% \mathrm{NaCl}$ addition (the last panel), peaks of $\mathrm{Al}, \alpha-\mathrm{Al}_{2} \mathrm{O}_{3}, \gamma-\mathrm{Al}_{2} \mathrm{O}_{3}$, and $\mathrm{NaCl}$ are identified. The detected $\mathrm{NaCl}$ in the combustion products testifies that $\mathrm{NaCl}$ does not react with $\mathrm{nAl}$ in steam. Based on some studies, ${ }^{\mathbf{4 2 , 5 1 , 5 2}}$ the crystalline form of oxide film in the oxidation of aluminum particles majorly includes $\alpha-\mathrm{Al}_{2} \mathrm{O}_{3}$ and $\gamma-\mathrm{Al}_{2} \mathrm{O}_{3}$. Also, $\alpha-\mathrm{Al}_{2} \mathrm{O}_{3}$ is the most stable crystalline phase, and possesses fairly good crystallization performance. It is found that the crystalline form of alumina oxide is varied near $67.3^{\circ}$. The peak intensity of $\gamma-\mathrm{Al}_{2} \mathrm{O}_{3}$ for nAl with $5 \mathrm{wt} \% \mathrm{KBH}_{4}$ addition or $5 \mathrm{wt} \% \mathrm{AP}$ addition is increased, indicating that the addition of $\mathrm{AP}$ or $\mathrm{KBH}_{4}$ hinders the crystalline form transformation from $\gamma-\mathrm{Al}_{2} \mathrm{O}_{3}$ to $\alpha-\mathrm{Al}_{2} \mathrm{O}_{3}$.

\section{Conclusions}

This work focuses on the effects of three additives on the ignition and combustion characteristics of nano-sized aluminum powder in steam. The primary conclusions of this study are summarized as follows:

(1) The addition of $\mathrm{KBH}_{4}$, AP or NaCl has a certain influence on the ignition and combustion temperatures. The optimal content ( $3 \mathrm{wt} \%$ ) of $\mathrm{KBH}_{4}$ improves the ignition and combustion performance of nano-sized aluminum powder in steam. In addition, the nano-sized aluminum powder with $3 \mathrm{wt} \% \mathrm{KBH}_{4}$ addition retains a high maximum combustion temperature $\left(1404^{\circ} \mathrm{C}\right)$ and a low ignition temperature $\left(428^{\circ} \mathrm{C}\right)$. On the other hand, the ignition temperature and the maximum combustion temperature both decrease with the increase of AP or $\mathrm{NaCl}$ content.

(2) The combustion process of nano-sized aluminum powder with $5 \mathrm{wt} \% \mathrm{KBH}_{4}$ or AP addition involves explosion-like intense burning, and produces many bright trajectories. However, adding $5 \mathrm{wt} \% \mathrm{NaCl}$ as additive, the bright burning zone not only shrinks but also produces less intense flame emission.

(3) The surface morphologies and sizes of combustion products are closely related to the addition of three additives. The combustion products of nano-sized aluminum powder without addition of additive consist of some large irregular blocks covered by a layer of floccules. For nano-sized aluminum powder with $5 \mathrm{wt} \% \mathrm{KBH}_{4}$ addition, the combustion products contain fluffy particles with an average diameter of about $1.0 \mu \mathrm{m}$. Adding $5 \mathrm{wt} \% \mathrm{AP}$, there are a lot of smooth spherical particles on the surface of much large structures in the combustion products, and the average diameter of these smooth spherical particles is approximately $2.0 \mu \mathrm{m}$. The combustion products of nano-sized aluminum powder with $5 \mathrm{wt} \% \mathrm{NaCl}$ addition mainly include rod-shaped and irregular particles. The lengths of these rodshaped particles are in the range of 2.8 to $12.4 \mu \mathrm{m}$ and the diameters of the particles are about $5.3 \mu \mathrm{m}$.

(4) The peaks of $\mathrm{Al}, \alpha-\mathrm{Al}_{2} \mathrm{O}_{3}$, and $\gamma-\mathrm{Al}_{2} \mathrm{O}_{3}$ are detected in the XRD patterns of all the combustion products examined. For nano-sized aluminum powder with $5 \mathrm{wt} \% \mathrm{KBH}_{4}$ addition, there is a $\mathrm{KBO}_{2}$ peak besides the peak of $\mathrm{Al}, \alpha-\mathrm{Al}_{2} \mathrm{O}_{3}$ and $\gamma-\mathrm{Al}_{2} \mathrm{O}_{3}$ due to the $\mathrm{KBH}_{4}$ hydrolysis. The addition of AP or $\mathrm{KBH}_{4}$ inhibits the crystal transforming from $\gamma-\mathrm{Al}_{2} \mathrm{O}_{3}$ to $\alpha-\mathrm{Al}_{2} \mathrm{O}_{3}$.

\section{Acknowledgements}

We greatly appreciate the financial support provided by National Natural Science Foundation of China (No. 51376007, 51676001 and 51206001) and Anhui Provincial Natural Science Foundation (No. 1608085ME104).

\section{References}

1 E. I. Shkolnikov, A. Z. Zhuk and M. S. Vlaskin, Renewable Sustainable Energy Rev., 2011, 15, 4611-4623.

2 L. Chen, W. Song, J. lv, X. Chen and C. Xie, Mater. Chem. Phys., 2010, 120, 670-675.

3 M. Diwan, D. Hanna, E. Shafirovich and A. Varma, Chem. Eng. Sci., 2010, 65, 80-87.

4 H. T. Huang, M. S. Zou and X. Y. Guo, Combust., Explos. Shock Waves, 2013, 49, 541-547.

5 M. S. Zou, R. J. Yang, X. Y. Guo and H. T. Huang, Int. J. Hydrogen Energy, 2011, 36, 6478-6483.

6 L. Y. Huang, Z. X. Xia, J. X. Hu and Q. W. Zhu, Sci. China: Technol. Sci., 2011, 54, 877-882. 
7 B. Sakintuna, F. Lamari-Darkrim and M. Hirscher, Int. J. Hydrogen Energy, 2007, 32, 1121-1140.

8 Y. M. Lee, N. S. Choi, J. H. Park and J. K. Park, J. Power Sources, 2003, 119, 964-972.

9 S. Xu, Y. Chen, X. Chen, D. Wu and D. Liu, Combust., Explos. Shock Waves, 2016, 52, 342-349.

10 G. A. Risha, S. F. Son, R. Yetter, V. Yang and B. Tappan, Proc. Combust. Inst., 2007, 31, 2029-2036.

11 H. T. Huang, M. S. Zou, X. Y. Guo, R. J. Yang and Y. K. Li, J. Power Sources, 2014, 246, 960-964.

12 V. Rosenband and A. Gany, Int. J. Hydrogen Energy, 2010, 35, 10898-10904.

13 G. P. Sutton and O. Biblarz, Rocket propulsion elements, John Wiley \& Sons, New York, USA, 2010.

14 M. Schiemann, J. Bergthorson, P. Fischer, V. Scherera, D. Taroatac and G. Schmidc, Appl. Energy, 2016, 162, 948965.

15 C. L. Yeh and K. K. Kuo, Prog. Energy Combust. Sci., 1996, 22, 511-541.

16 D. S. Sundaram, V. Yang and V. E. Zarko, Combust., Explos. Shock Waves, 2015, 51, 173-196.

17 T. F. Miller and J. D. Herr, AIAA Pap., 2004, 4037.

18 D. S. Sundaram, V. Yang, T. L. Connell and G. A. Risha, Proc. Combust. Inst., 2013, 34, 2221-2228.

19 S. Elitzur, V. Rosenband and A. Gany, Int. J. Hydrogen Energy, 2014, 39, 6328-6334.

20 H. Z. Wang, D. Y. C. Leung and M. K. H. Leung, Renewable Sustainable Energy Rev., 2009, 13, 845-853.

21 P. Dupiano, D. Stamatis and E. L. Dreizin, Int. J. Hydrogen Energy, 2011, 36, 4781-4791.

22 W. Ki, V. Shmelev, S. Finiakov, Y. Cho and W. Yoon, Combust. Flame, 2013, 160, 2990-2995.

23 J. Sabourin, G. Risha, R. Yetter, S. Son and B. Tappan, Combust. Flame, 2008, 154, 587-600.

24 T. D. Wood, M. A. Pfeil, T. L. Pourpoint and S. F. Son, AIAA Pap., 2009, 4877.

25 W. Yang, T. Zhang, J. Zhou, W. Shi, J. Liu and K. Cen, Energy, 2015, 88, 537-543.

26 D. Quijano, A. L. Corcoran and E. L. Dreizin, Propellants, Explos., Pyrotech., 2015, 40, 749-754.

27 M. Schoenitz, S. M. Umbrajkar and E. L. Dreizin, J. Propul. Power, 2007, 23, 683-687.

28 V. Shmelev, H. Yang and C. Yim, Int. J. Hydrogen Energy, 2016, 41, 14562-14572.

29 W. Yang, T. Zhang, J. Liu, J. Zhou and K. Cen, Energy, 2015, 93, 451-457.
30 A. V. Vasilev, V. V. Gorbunov and A. A. Shidlovskii, The effect of certain additives on critical diameter and combustion rates of mixtures of aluminium with gelled water, AD-A000210, 1974.

31 D. S. Sundaram, V. Yang, T. L. Cormell and G. A. Risha, AIAA Pap., 2011, 603.

32 Y. Sun and B. Zhu, Ind. Eng. Chem. Res., 2011, 50, 1413614141.

33 E. Shafirovich, V. Diakov and A. Varma, Combust. Flame, 2006, 144, 415-418.

34 E. Shafirovich, V. Diakov and A. Varma, Int. J. Hydrogen Energy, 2007, 32, 207-211.

35 E. Czech and T. Troczynski, Int. J. Hydrogen Energy, 2010, 35, 1029-1037.

36 M. Q. Fan, F. Xu and L. X. Sun, Energy Fuels, 2007, 21, 22942298.

37 S. Chaturvedi and P. N. Dave, J. Saudi Chem. Soc., 2013, 17, 135-149.

38 J. Zhi, L. S. Fen, L. Kai, W. T. Fan, Z. G. Chui, W. Hua and M. X. Mei, AIAA J., 2006, 44, 1463-1467.

39 K. Deshpande, A. Mukasyan and A. Varma, Chem. Mater., 2004, 16, 4896-4904.

40 M. A. Trunov, M. Schoenitz and E. L. Dreizin, Combust. Theory Modell., 2006, 10, 603-623.

41 I. Levin and D. Brandon, J. Am. Ceram. Soc., 1998, 81, 19952012.

42 V. Rosenband, Combust. Flame, 2004, 137, 366-375.

43 C. R. M. Wronski, Br. J. Appl. Phys., 1967, 18, 1731-1737.

44 J. J. Granier and M. L. Pantoya, Combust. Flame, 2004, 138, 373-383.

45 E. M. Hunt, K. B. Plantier and M. L. Pantoya, Acta Mater., 2004, 52, 3183-3191.

46 V. V. Boldyrev, Thermochim. Acta, 2006, 443, 1-36.

47 S. K. Som and A. Datta, Prog. Energy Combust. Sci., 2008, 34, 351-376.

48 E. Czech and T. Troczynski, Int. J. Hydrogen Energy, 2010, 35, 1029-1037.

49 B. U. Yoo, H. H. Nersisyan, H. Y. Ryu, J. S. Lee and J. H. Lee, Combust. Flame, 2014, 161, 3222-3228.

50 Y. Sun and B. Zhu, Ind. Eng. Chem. Res., 2011, 50, 1413614141.

51 S. Mohan, L. Furet and E. L. Dreizin, Combust. Flame, 2010, 157, 1356-1363.

52 M. Schoenitz, B. Patel, O. Agboh and E. L. Dreizin, Thermochim. Acta, 2010, 507, 115-122. 